\title{
IN HA LTSÜBERSICHT.
}

1. Die Autobiographie Hadrians . . . . . . . . . . . . 3

2. Die Vita Hadriani des Spartianus .. . . . . . . . . . . 11

3. Dio Cassius . . . . . . . . . . . . . . . . . . . . 54

4. Die Quellen für die Militärreorganisation Hadrians :

a) Dio und Spartian . . . . . . . . . . . . . 61

b) Vegetius . . . . . . . . . . . . . . . . . . 64

c) Arrians Taktik und Hadrians Allokution an die Legion von Lambaesis. - Resultate . . . . . . . 71

5. Dio und Apollodor . . . . . . . . . . . . . . . . . . . 89

A n h a ng.

Das Monumentum Ancyranum und die kaiserlichen Autobiographien . . . . . . . . . . . . . . . . . . . 98 
